\title{
Together in the world! Postfoundationalism re-discovered in Ubuntu
}

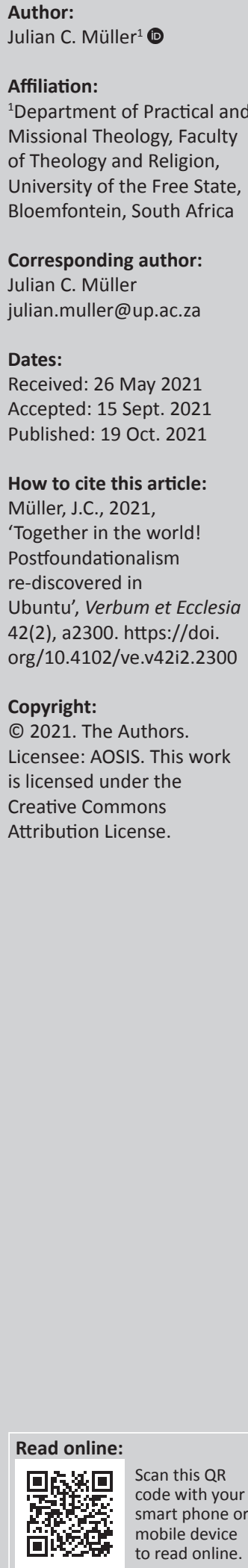

This article investigates two questions: (1) What is the significance of a typical western philosophical concept like postfoundationalism for the African context? (2) Can Ubuntu be the key or the bridge between two seemingly distant philosophical worlds? I have been involved in two major research projects: firstly, the exploration of the postfoundationalist paradigm and the significance of it for practical theology; secondly, a study of Ubuntu and its value for human and social development in Africa.

Intradisciplinary and/or interdisciplinary implications: This article is an ethnographic journey in which I revisit and reflect on those two projects and the link between them. The reflection focuses on four concepts: interdisciplinary practice, colonialism and whiteness, fiction and research, and holism.

Keywords: postfoundationalism; Ubuntu; western philosophical concept; African context; philosophical worlds.

\section{Problem statement}

The problem or issue to be investigated in this article can be formulated in two questions:

1. What is the significance of a typical western philosophical concept like postfoundationalism for the African context?

2. Can Ubuntu be the key or the bridge between two seemingly distant philosophical worlds?

To reflect on these questions, I have decided to retract a section of my academic journey, which is also intertwined with Wentzel van Huyssteen's career. During the last two decades I have been involved in two major research projects: firstly, the exploration of the postfoundationalist paradigm and the significance of it for practical theology ${ }^{1}$; secondly, a study of Ubuntu and its value for human and social development in Africa. ${ }^{2}$ This article is an ethnographic journey in which I revisit and reflect on those two projects and the link between them.

\section{Ethnographic journey}

Ethnography as epistemology is in line with the narrative understanding and creation of knowledge (see Bochner \& Ellis 1996; Müller 2017:86). It is an autobiography embedded in the cultural and contextual story. In this case, the context is my research since 2002 and especially since 2013 with the Ubuntu project, which needs to be understood and interpreted against the background of meeting with Wentzel van Huyssteen and the exposure to postfoundationalist thinking. Ethnography is dependent on memory. The researcher does some backtracking and revisits places of meaning. It is a journey that can be called memory work. In the research setting, memory work is more than just remembering and telling stories from the past. According to Mitchell et al. (2011), it is:

[T]o facilitate a heightened consciousness of how social forces and practices, such as gender, race, and class, affect human experiences and understanding of how individuals and groups can take action in response to these social forces and practices in ways that can make a qualitative difference to the present and the future. (p. 1)

Before I start to tell the story of my connection with Van Huyssteen's theories and the research projects that followed thereafter, it is important to point out that 'memory work' is not a mere 1.I have written a number of articles on the meaning of postfoundationalism for Practical Theology. See them listed in the bibliography. 2.The result of this research project is to be found mainly in two publications, namely a special edition of Verbum et Ecclesia (Vol. 36 , No 2, 2015) and the book Unfolding Narratives of Ubuntu in Southern Africa (2019). Both are listed in the bibliography.

Note: Special Collection: Festschrift for Wentzel van Huyssteen. 
recollection of distant events of the past, but a 'creative rupture' (Müller, Kruger \& Jeong 2021:134). Our memories are always reworked in the light of present experiences.

The journey started during the last quarter of 2002 when my wife and I had the opportunity to spend two months on the campus of Princeton Theological Seminary. We were accommodated in Payne Hall, which was situated right next to the seminary house in which Wentzel and Hester van Huyssteen then lived.

We were overwhelmed with the hospitality and were warmly welcomed on the campus of the Princeton Theological Seminary. As an international research scholar, I was welcomed with openness and warmth. Easy access to all the facilities of the Seminary was immediately arranged and I was invited to attend meetings, lectures, and seminars. I was privileged to meet with colleagues within my discipline (practical theology), but the big surprise was the opportunity to get to know the Van Huyssteens as our next-door neighbours. I was aware of the fact that Wentzel was a reckoned and well-known international academic, but I also discovered him as an approachable and humble colleague. $\mathrm{He}$ and Hester welcomed us with open arms as their friends and that was the start of a precious and lasting friendship. ${ }^{3}$

Before that visit to Princeton, I was familiar with the name Wentzel van Huyssteen. He was and is a well-known and respected South African theologian, who achieved international recognition. He was appointed into the prestigious position of the James I. McCord Professor of Theology and Science at Princeton Theological Seminary. Before my visit to Princeton, I have read his book Teologie as Kritiese Geloofsverantwoording, which was a fresh and alternative voice in the very conservative Afrikaans theological literature of the time. Therefore, when I arrived at Princeton I already had very high regard for this famous theologian, but I have never met him personally.

At Princeton, I was exposed to Van Huyssteen's theological thinking. Although his writings were not in my specific field (Practical Theology), I immediately started to read his latest books, which inspired numerous discussions with him about postfoundationalist theology. During that time, he received the invitation to present the very prestigious Gifford Lectures ${ }^{5}$ at the University of Edinburgh. It was a very special time in his life and we were so fortunate to share it with him. The honour of being the first Princeton Seminary professor to deliver the Gifford Lectures was well celebrated by us with them. His enthusiastic preparation for the lectures provided more impetus to our discussions on theology and postfoundationalism. My interest was especially focused on the meaning of the postfoundationalist paradigm for practical theology.

3.1 have written about this personal encounter with the Van Huyssteens in my 2004 and 2011 articles (see bibliography).

4.This book was awarded the Andrew Murray Award in 1987. To me this was the first theological work in Afrikaans which was thinking outside of the confessional boundaries of the traditional Afrikaans theological world of the time.

5.Van Huyssteen's Gifford Lectures were later in 2006 published under the title of Alone in the World.
By the time we returned home in November of that year, I was convinced of the profound meaning of the concept of postfoundationalism for theology. Since then I have published at least seven articles on the meaning of the concept for Practical Theology. In one of these articles, I specifically tried to bring the concept of Ubuntu and Postfoundationalism in conversation with each other. ${ }^{6}$ The background explanation for this effort is my involvement with an Ubuntu research project from 2013 to 2017. ${ }^{7}$ This research project overshadowed about 6 years of my life and culminated in the publication 'Unfolding Narratives of Ubuntu in Southern Africa'. The book was edited by myself, Prof. Sheila Trahar of Bristol University, and Dr Master's John Eliastam, one of my doctorate candidates. It was published by Routledge and consists of 11 chapters, which covered the research, which I, together with my team of researchers conducted as part of the Templeton project.

With all these encounters and experiences, namely my introduction to postfoundationalism through Wentzel van Huyssteen, my writing project over many years in which I developed a model for Practical Theological research based on postfoundationalist principles, and my involvement as team leader of an Ubuntu research project, I am now compelled to ask the critical question: Did I find any meaningful linkages between the two concepts, postfoundationalism, and Ubuntu? The aim of this article is to reflect on this question.

The writing of this article forced me to do some backtracking and reflect on the questions which I formulated at the beginning. This reflection was also inspired by my exposure to Ubuntu because one of the key concepts in Ubuntu thinking is holism or wholeness. Ubuntu is an ongoing effort to connect and to heal. The same can be said about postfoundationalism. In a previous article, I made the following statement: 'The postfoundationalist approach is an integration of various perspectives: ecohermeneutics, narrative therapy, narrative theology, narrative research, social-constructionism, autobiography, and ethnobiography'. (Müller2015:5).Oneof thekeyconceptsinpostfoundationalism is transversality and therefore interdisciplinary action. Therefore, both of these paradigms, two seemingly distant worlds of thought, namely postfoundationalism and ubuntu inspired me to reflect on connections, similarities, mutual language, and corresponding ideas.

\section{Reflection}

I believe that the following concepts, which we encountered whilst doing the Ubuntu research, can serve as the framework for a reflection on the question of this article:

6.'Exploring "nostalgia" and "imagination" for ubuntu-research: A Postfoundationa perspective' In VE Vol. 36 No 2. 2015

7.'The meaning and value of Ubuntu in human and social development in Africa' was a three-year research project, funded by the Templeton World Aid Foundation, which was done at the University of Pretoria. 
1. Interdisciplinary practice

2. Colonialism and whiteness

3. Fiction and research

4. Holism

These four questions will be considered and reflected on without necessarily providing answers. The aim of this reflection is not to provide answers, but to shed some light on the issues which have been encountered on this research journey.

\section{Interdisciplinary practice}

When I was approached by the Vice-Chancellor of the University of Pretoria to become part of a team of researchers on the theme of Ubuntu, I was immediately interested and excited about the prospect of interdisciplinary research on such a high level. The original team that was brought together consisted of the leader, Prof. James Ogude, who is a specialist in African Literature; Prof. Maxi Schoeman from Political Science; Prof. Christof Heyns from Law; and myself as a Practical Theologian. In the early days of the project, we had to find ways of working together and to get a big project (3 years funded by the Templeton World Charity Fund) going. The four of us were not well acquainted with each other. We knew enough of each other to have mutual respect, but we had to build trust and find a modus operandi, which could allow us to work together on this project.

I was very motivated and even excited to be engaged in an interdisciplinary project. My subject, Practical Theology is the one theological discipline that cannot function without an interdisciplinary approach. In my publications, I have tried to develop an interdisciplinary framework based on the postfoundationalist concept of transversal rationality. The result was the so-called 'Seven Movements' for practical theology. This model or framework was used and implemented by several of my Masters and PhD-students in their research and I was convinced of both the necessity and the usability of transversal rationality for interdisciplinary work.

But I was much surprised and shocked when I tried to introduce the postfoundationalist concepts to my new colleagues in the Ubuntu team. They listened to me with due respect but were not convinced that we should adopt such a strange and new modus for the research on Ubuntu. All the participants were full-time academics with a huge baggage of research and teaching. Thus there was a willingness to listen respectfully to each other and take note of the other's work and findings, but they were not open to the painstaking route of finding the inherent rationalities within our different disciplines.

Fortunately, the research project was structured in such a way that each of us as team leaders could gather our subteam of researchers to work within our different disciplines.
My team consisted of Ph.D. and Masters students and a consultant academic from Bristol University (Dr Sheila Trahar, professor in Education). We were all trained in and used to interdisciplinary work. Practical Theology is in nature an in-between or a hybrid discipline. It functions between Theology and the Human and Social sciences and therefore has to work inter- or trans-disciplinary. Therefore, there was ample opportunity to fulfil my need for interdisciplinary research based on transversal rationality. The publication, Unfolding Narratives of Ubuntu in Southern Africa (eds. Müller, Eliastam \& Trahar 2019) is the result of this trans-disciplinary work within my team.

The concept of Ubuntu is in itself interdisciplinary. No discipline can claim Ubuntu to belong to that specific subject.

\section{Colonialism and whiteness}

Our research on Ubuntu brought us into the dynamic field of perceptions, expectations, and biases based on culture, race, and power. In an article by Prof. Sheila Trahar and myself (Müller \& Trahar 2016), we reflected on our subjectivity and our whiteness, our colonial baggage that is always with us in Africa, and how our Ubuntu research project was influenced by that baggage.

What is 'whiteness' and how is it used and understood in this article? The following description given by Steyn (2005) can help us:

I believe it is best understood as an ideologically supported social positionality that has accrued to people of European descent as a consequence of the economic and political advantage gained during and after European colonial expansion. (p. 121)

This rather academic definition is made a bit more accessible in an interview with Richard Rohr on white privilege:

'White privilege is largely hidden from our eyes if we are white. Why? Because it is structural instead of psychological, and we tend to interpret most things in personal, individual, and psychological ways. Since we do not consciously have racist attitudes or overt racist behavior, we kindly judge ourselves to be open-minded, egalitarian, "liberal," and therefore surely not racist. Because we have never been on the other side, we largely do not recognize the structural access, the trust we think we deserve, the assumption that we always belong and do not have to earn our belonging, the "we set the tone" mood that we white folks live inside of - and take totally for granted and even naturally deserved. Only the outsider can spot all these attitudes in us. It is especially hidden in countries and all groupings where white people are the majority.' (Huffington Post, 15 January 2015)

\section{I conclude with Dick (2021):}

$[W]$ hiteness is seen as a position, attitude, or space of structural privilege, characterized by an ignorance of privilege. Hence, whiteness is the lack of insight into such a racial order, where white people are unable to comprehend that opportunities are racialized. (p. 69) 
Based on this understanding, I would like to reflect shortly on two aspects that we encountered during our Ubuntu research:

- Whiteness as an issue in doing Ubuntu research

- Order/disorder in Ubuntu research

Strangely enough, I did not think about my whiteness at the beginning. The honour of being part of the project as a theologian was overwhelming. I was also guided by my conviction that research is in any case always subjective and that the researcher is not awarded credibility by any attribute or status on his or her side, but by the integrity with which the research is done. I had bona fide intentions with this research. But then later in one of the colloquia that were organised, and where I had to present and defend my research and research intentions, I was confronted by critique and scepticism. The questions were about western and colonial prejudice and the legitimacy of a white Afrikaner male being in charge of a research project on Ubuntu. At first, I was very angry that my good intentions and hard work for this project could be doubted, but then I realised that my position and participation in this research project could not be taken for granted.

After much reflection and soul-searching, I realised that I should accept the fact that people would frown upon me as a white Afrikaner male researching Ubuntu. It is not an unproblematic situation. My first reaction was to defend myself and my motives. It took me a long time to reach the position where I am now, where I acknowledge my fragile and vulnerable position as a researcher, and where I realise that it is necessary to reflect on my involvement in this research with as much subjective integrity as possible

Marguerite Müller (2016) calls this position the building of 'scaffolding':

It is tempting to envision ourselves as being critically conscious, shaking off the oppressive baggage, and becoming triumphant agents of change. It is, however, more realistic to see our involvement and contributions as an effort to build some 'scaffolding'. We can perhaps reach political correctness, but our aim should rather be honesty in dialogue, with the danger of becoming oppressive again. But, hopefully with the possibility of being confronted and challenged again and again. (p. 43)

This is in line with postfoundationalist thinking where the emphasis is put on the process rather than on what is reached.

The second point of reflection has to do with the preference for order, which is the stereotypical western approach. The preference for order comes with whiteness. Order is maintained by categorising and analysing. With language categories, things are put in place to control a complex environment. From there the emphasis on research methods and models.

As part of the research project on Ubuntu, we have listened to many speeches and lectures. With definitions and all kinds of academic language categories, like 'theory', 'praxis', 'problem statement', and so on, researchers are trying to organise the field and make it governable for us as western researchers. The results are not convincing, because again and again, we are confronted with the paradoxes and inconsistencies of what we call 'Ubuntu'. The growing questions are as follows: Is it an acceptable research practice to subject Ubuntu to whiteness with all these research methods? Should we not rather allow Ubuntu to take us on a journey and teach us in its way?

Perhaps if we as researchers (Black and White) have taken Postfoundationalism more seriously and brought it more effectively in conversation with Ubuntu, we would have been more successful in building the 'scaffolds' for responsible research on this evasive theme.

\section{Fiction and research}

The researchers in the Ubuntu project mostly struggled to produce a clear and comprehensive definition of Ubuntu. What they did achieve was to point to the examples of embodied action in specific contexts. They shared stories and these stories not only exemplified Ubuntu but described it in a manner that was both nuanced and evocative. The telling of such rich stories convinced us that to strip Ubuntu of its storied nature and to try and present it as some kind of abstract philosophy would be to separate it from its African worldview.

Thus, we are drawn to narrative forms of inquiry, which included the use of fiction as part of this research tradition. Although the use of narrative and fiction writing are well-established forms of inquiry, for many the presence of the words 'fiction' and 'narrative' alongside 'research' seem oxymoronic and create questions and objections about validity and trustworthiness. Scholars working in the positivistic and post-positivist tradition would regard knowledge to be solid and data to be hard. While on the other hand 'Knowledge as a process, a temporary state, is scary to many' (Eisner 1997:7). However, it is precisely the postfoundationalist understanding of knowledge (epistemology) that opened the perspective on the 'temporary state' of research. It is this emphasis on the process of discovering knowledge that draws us to what fiction could make possible. Our exposure to postfoundationalist thinking indeed helped us to shift our focus to the process of knowledge creation, which lead us to the point where we would rather seek to uncover new questions rather than draw definite conclusions.

Van Huyssteen's postfoundationalist approach also opened for us the notion of aesthetic knowledge (Van Huyssteen 2012:49, 285). In contrast with Wade (2008:17) who explains narrative approaches as '....aesthetic forms which are seen as the writing of literature and not the writing of scientific research', we became convinced that aesthetic forms, like storytelling, should be seen as part of 'scientific research'. One of our researchers, John Eliastam, has formulated it as follows (in eds. Müller et al. 2019): 
The use of fiction allowed me to blend multiple encounters into a fictional composite (Eliastam 2016) and express both the challenge and enlightenment that resulted from these encounters. Moving further into my experimentation with fiction, I discovered that it lent authenticity to the voices of those who participated in the research. I have become increasingly convinced that to disconnect statements made by co-researchers from their context and present them as isolated utterances were to strip them of meaning. By crafting a plot and creating characters, fiction was able to present their stories as part of a wider web of stories and preserve the multi-layered complexity that is often characteristic of social phenomena. (p. 16)

\section{Holism}

Finally, postfoundationalist thinking, with the emphasis on transversal rationality, helped us to overcome the typical Western hyper-individualistic understanding of reality and to find a link to Ubuntu, which functions with the opposite perspective of life. Ubuntu is the African concept of personhood. Persons depend on other persons and this idea is expressed in the well-known saying: umuntu ngumuntu ngabantu. This means that a person is a person through other persons. Or, in the words of Archbishop Emeritus Tutu (2000:35): 'I am human because I belong' and 'Social harmony is for us the summum bonum - the greatest good'.

\section{The open-ended questions}

In the Ubuntu research project, we have tried to open ourselves to be taken into the Ubuntu story. But still, even the narrative way of doing research is coined and created in research dominated by whiteness. The question we need to reflect on, and which we need to keep on asking ourselves is whether we have been constantly and sufficiently aware of what we are bringing into the process with our whiteness. Did we succeed in allowing the Ubuntu story as it is, to tell and inform us? To what extent have we, with our problem statements and research questions, constructed a concept of Ubuntu, which might not exist out there?

What is the ideal towards which we would like to emancipate with our research and did we reflect sufficiently on how much our ideas about better practice and the 'positive aspects' of Ubuntu were the results of our whiteness? What is the grand narrative which we have simply taken for granted and based on which we are making moral and ethical judgments about Ubuntu?

On the other hand, it is because of our exposure to the world and language of Ubuntu, that we have been sensitised towards these questions. It is perhaps one of the most important results of our project that we have been empowered to reflect on something like whiteness and research. We have been influenced by Ubuntu on a level that we perhaps did not expect. Where we started with rather objective and distant 'research questions' about what Ubuntu is, we have now come to a place where we would like to be guided by Ubuntu in the way we do our research. This brings us back to the concept of postfoundationalism.

With Postfoundationalism and Ubuntu as our guideposts, we continue to ask questions about the following: interdisciplinary practice, colonialism and whiteness, fiction and research, and holism.

\section{Acknowledgements Competing interests}

The author declares that he has no financial or personal relationships that may have inappropriately influenced him in writing this article.

\section{Author's contributions}

J.C.M. is the sole author of this article.

\section{Ethical considerations}

This article followed all ethical standards for research without direct contact with human or animal subjects.

\section{Funding information}

This research received no specific grant from any funding agency in the public, commercial or not-for-profit sectors.

\section{Data availability}

Data sharing is not applicable to this article as no new data were created or analysed in this study.

\section{Disclaimer}

The views and opinions expressed in this article are those of the author and do not necessarily reflect the official policy or position of any affiliated agency of the author.

\section{References}

Bochner, A.P. \& Ellis, C., 1996, 'Talking over ethnography', in C. Ellis \& A.P. Bochner (eds.), Composing ethnography: Alternative forms of qualitative writing, pp. 13-45, Sage, London.

Dick, L., 2021, 'Becoming white: The story of being assimilated into the white habitus of Bloemfontein', in J. Kurzwelly \& L. Escobedo (eds.), Migrants thinkers storytellers: Negotiating meaning and making life in Bloemfontein, South Africa, pp. 64-87, HSRC Press, Cape Town.

Eisner, E.W., 1997, 'The promise and perils of alternative forms of data representation', Educational Researcher 26(6), 4-10. https://doi.org/10.3102/ $0013189 \times 026006004$

Eliastam, J., 2016, 'Interrupting separateness, disrupting comfort: An autoethnographic account of lived religion, ubuntu and spatial justice', HTS Teologiese Studies/Theological Studies 72(1), a3488. https://doi.org/10.4102/ hts.v72i1.3488

Mitchell, C., Strong-Wilson, T., Pithouse, K. \& Allnutt, S., 2011, Memory and pedagogy, Routledge, New York, NY.

Müller, J., 2015, “Exploring "nostalgia" and "imagination" for ubuntu-research: A postfoundational perspective', Verbum et Ecclesia 36(2), a1432. https://doi. org/10.4102/ve.v36i2.1432

Müller, J.C., 2017, 'African postfoundational practical theology', Acta Theologica 37(1), 86-96. https://doi.org/10.18820/23099089/actat.v37i1.6 
Müller, J., Eliastam, J. \& Trahar, S. (eds.), 2019, Unfolding narratives of Ubuntu in Southern Africa, Routledge, New York, NY.

Müller, J. \& Trahar, S., 2016, 'Facing our whiteness in doing Ubuntu research: Finding spatial justice for the researcher', HTS Teologiese Studies/Theological Studies 72(1), a3510. https://doi.org/10.4102/hts.v72i1.3510

Müller, M., 2016, 'A collaborative self-study of educators working towards anti-oppressive practice in higher education', PhD thesis, University of the Free State, Bloemfontein.

Müller, M., Kruger, F. \& Jeong, J.H., 2021, “"Do you miss kimchi?”: A collaborative arts-based narrative of education and migration', in J. Kurzwelly \& L. Escobedo (eds.), Migrants thinkers storytellers. negotiating meaning and making life in Bloemfontein, South Africa, pp. 132-150, HSRC Press, Cape Town.
Steyn, M., 2005, "White Talk": White South Africans and the management of diasporic whiteness', in A.J. López (ed.), Postcolonial whiteness: A critical diasporic Whiteness', in A.J. López (ed.), Aostcolonial Whiteness. A critical reader on race and empire, pp. 119-135, State University of New York Press,
New York, NY.

Tutu, D., 2000, No future without forgiveness: A personal overview of South Africa's truth and reconciliation commission, Random House, Parktown.

Van Huyssteen, J.W., 2012, Alone in the world? Human uniqueness in science and theology: The Gifford lectures, The University of Edinburgh, Spring 2004, Eerdmans, Grand Rapids, MI.

Wade, D.G., 2008, 'The viability of fictional research writing in academe: Explorations of process and product', PhD dissertation, Oklahoma University. 